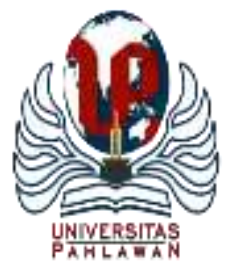

Edukatif : Jurnal Ilmu Pendidikan Volume 3 Nomor 5 Tahun 2021 Halm 3371 - 3375

EDUKATIF: JURNAL ILMU PENDIDIKAN

Research \& Learning in Education

https://edukatif.org/index.php/edukatif/index

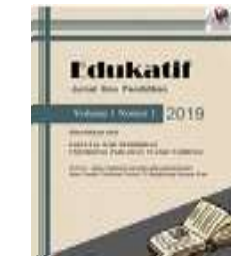

\title{
Meningkatkan Hasil Belajar Siswa pada Pelajaran PPKn dengan Menerapkan Model Paradigma Pedagogi Reflektif di Sekolah Dasar
}

\author{
Kamarudin \\ Universitas Muhammadiyah Buton, Baubau, Indonesia \\ E-mail : akamarudin1453@gmail.com
}

\begin{abstract}
Abstrak
Penelitian ini menggunakan jenis Penelitian Tindakan Kelas (PTK) dengan II siklus dan untuk setiap siklusnya terdiri dari perencanaan, pelaksanaan, observasi dan refleksi melalui penerapan model pembelajaran Paradigma Pedagogi Reflektif (PPR) pada mata pelajaran Pendidikan Pancasila dan Kewarganegaraan (PPKn) materi Peristiwa Lahirnya Pancasila dan Peran pancasila dalam menjaga keberagaman bangsa. Penelitian ini dilakukan di Sekolah Dasar Negeri 110 buton Kecamatan Wolowa. Dan subjek dari penelitian ini adalah siswa kelas V dengan jumlah 19 orang. Berdasarkan hasil penelitian, dapat diambil kesimpulan bahwa hasil belajar siswa sebelum tindakan hanya mendapatkan nilai tara-rata senesar 64,41 atau 21\% tingkat keberhasilannya. Setelah diterapkannya model pembelajaran Paradigma Pedagogi Reflektif (PPR) pada siklus I hasil belajar Pendidikan Pancasila dan Kewarganegaraan (PPKn) siswa memiliki nilai rata-rata 70\% atau 52,6\% tingkat keberhasilan siswa. Pada siklus II diperoleh nilai rata-rata $81,57 \%$ atau $84,21 \%$ tingkat keberhasilan para siswa. Penelitian Tindaka Kelas (PTK) ini dapat dikatakan meningkat dengan mengunakan model pembelajaran Paradigma Pedagogi Reflektif (PPR).
\end{abstract}

Kata Kunci : Hasil belajar, Model Paradigma Pedagogi Reflektif.

\begin{abstract}
This study uses Classroom Action Research (CAR) with II cycles and for each cycle consists of planning, implementing, observing and reflecting through the application of the Reflective Pedagogical Paradigm learning model (PPR) on the subject of Pancasila and Citizenship Education (PPKn) material for the Birth of Pancasila. and the role of Pancasila in maintaining national diversity. This research was conducted at the 110 Buton State Elementary School, Wolowa District. And the subjects of this study were students of class $V$ with a total of 19 people. Based on the results of the study, it can be concluded that student learning outcomes before the action only get an average score of 64.41 or $21 \%$ success rate. After the implementation of the Reflective Pedagogical Paradigm learning model (PPR) in the first cycle, the learning outcomes of Pancasila and Citizenship Education (PPKn) students have an average score of $70 \%$ or $52.6 \%$ of students' success rates. In the second cycle, the average score of $81.57 \%$ or $84.21 \%$ of the students' success rate was obtained. This Classroom Action Research (CAR) can be said to increase by using the Reflective Pedagogical Paradigm (PPR) learning model.
\end{abstract}

Keywords: Learning outcomes, Reflective Pedagogical Paradigm Model.

Copyright (c) 2021 Kamarudin

$\triangle$ Corresponding author

Email : akamarudin1453@gmail.com

DOI $\quad$ : https://doi.org/10.31004/edukatif.v3i5.918

ISSN 2656-8063 (Media Cetak)

ISSN 2656-8071 (Media Online)

Edukatif : Jurnal Ilmu Pendidikan Vol 3 No 5 Tahun 2021 p-ISSN 2656-8063 e-ISSN 2656-8071 
3372 Meningkatkan Hasil Belajar Siswa pada Pelajaran PPKn dengan Menerapkan Model Paradigma Pedagogi Reflektif di Sekolah Dasar - Kamarudin

DOI: https://doi.org/10.31004/edukatif.v3i5.918

\section{PENDAHULUAN}

Pendidikan Pancasila dan Kewarganegaraan (PPKn) merupakan salah satu mata pelajaran yang diajarkan di Sekolah Dasar. Pendidikan Pancasila dan Kewarganegaraan (PPKn) adalah pendidikan yang mengarahkan siswa untukmenjadi warga negara yang demokratis, yang menghargai perbedaan, danmencintai keadilan dan kebenaran.(Ananda 2012). Pendidikan Pancasila dan Kewarganegaraan merupakan (PPKn) matapelajaran dimana didalamnya memuat pendidikan karakter yang ditujukan untukanak-anak di Indonesia. Pendidikan karakter merupakan pendidikan yang mengembangkan nilai dari pandangan hidup bangsa, agama, dan budaya yangdirumuskan dalam tujuan pendidikan nasional (Omeri 2005).

Tujuan pendidikan nasional adalah menjadikan warga negara demokratis dan bertanggung jawab. Sejalan dengan itu, permendiknas nomor 22 tahu 2006 tentang standar isi menjelaskan bahwa PPKn merupakan satu jenis pelajaran yang fokus dalam membentuk warganegara yang memahami dan mampu melaksanakan hak dan kewajiban untuk menjadi warga negara Indonesia yang berahlak mulia, berkarakter, cerdas, terampil (Zhafran 2020).

PPKn bertujuan untuk meningkatkan dan memperbaiki kualitas cara berpikir dan kualitas rasa, serta kepekaanpeserta didikdalam rangka mengetahui, menghayati, jugasebuah upaya untuk mewujudkan nilai-nilai kehidupan, khususnya nilai-nilai Pancasila (Wahana and Mayasari 2007).

Pendidikan merupakan usaha sadar yang bertujuan guna meningkatkan kualitas insanpada pelaksanaannya berada dalam sebuah proses yang kontinyu dalam setiap jenis jenjang pendidikan. Pendidikan merupakan kegiatan yang terjadi dengan sengaja dan terencana berdasarkan proses pelaksanaan bimbingan, tuntunan kepada anak sehingga mempunyai kecakapan intelegensi, emosi serta spiritual sehingga menjadi insan kamil dalam hidup dan kehidupannya nanti.(Zulfiati 2014) John Dewey, mendefinisikan pendidikan (education) sebagai langkahmembentuk kecakapan yang mendasar secara intelektual dan emosional ke arah perubahandalam kehidupan manusia (Pranyoto 2020).

Pendidikan merupakan upaya meningkatkan kualitas setiap individu, secara langsung disiapkan untuk menopang dan mengikuti perkembangan ilmu pengetahuan dan teknologi dalam meningkatkan mutu pendidikan yang sejalan dengan proses belajar mengajar. Pendidikan bertujuan merubahperilaku manusia yang mengalami pendidikan terjadi perubahan-perubahan.(Sudiyono and Karmini 2020) Guru mempunyai peran utama yakni instruktur atau fasilitator pemberi arah kepada peserta didik terkait dengan sumber belajara baru, memfasilitasi dalam mengadakan kontak-kontak dan memberikan bekal kepada peserta didik dengan berbagai macam sarana yang bermanfaat (Widodo, Renggani, and Sukarjo 2018).

Beberapa dekade ini, pendidikan mengalami banyak pembaharuan atau inovasi pendidikan. Inovasi yang terjadi dalam bidang pendidikan, antara lain ialah menejemen pendidikan, metodologi pengajaran, media, sumber belajar, pelatihan guru, implementasi kurikulum dan lain sebagainya (Fathurrochman 2017).

Berdasarkan uraian di atas dapat diketahui bahwa diantara inovasi yang harus dilakukan dalam pendidikan adalah metode dari pendidikan itu sendiri, termasuk juga penggunaan media dan sumber belajar yang tepat. Hal ini berkaitan dengan proses pembelajaran. Oleh karena itu, untuk mencapai hasil pembelajaran yang optimal dibutuhkan guru yang aktif, inovatif, kreatif dan selalau mempunyai keinginan untuk memperbaiki dan meningkatkan mutu pembelajaran dikelas dengan sebuah metode pelajaran yang sesuai materi yang akan di ajarkan dengan tujuan pembelajaran yang ingin dicapai. Dengan demikian dalam pembelajaran Pendidikan Pancasila dan Kewarganegaraan (PPKn) mengenai peristiwa mengisi kemerdekaan perlu adanya menerapan model pembelajaran Paradigma Pedagogi Refrektif (PPR) agar siswa semangat dan tidak merasa bosan dalam proses pembelajaran. Sehingga dapat meningkatkan pemahaman siswa, keaktifan siswa, dan hasil belajar siswa pada pokok pembahasanperistiwa lahirnya pancasila dan peran pancasila dalam menjaga keberagaman bangsa. 
3373 Meningkatkan Hasil Belajar Siswa pada Pelajaran PPKn dengan Menerapkan Model Paradigma Pedagogi Reflektif di Sekolah Dasar - Kamarudin

DOI: https://doi.org/10.31004/edukatif.v3i5.918

\section{METODE PENELITIAN}

Penelitian ini merupakan Penelitian Tindakan Kelas (PTK) yang dilaksanakan dalam dua (2) tahapan, dimana tiap-tiap tahap dilaksanakan sesuai dengan perubahan yang dicapai faktor-faktor yang diselidiki. Sebagai penjajakan awal maka terlebih dahulu tes awal (pretes)yang berfungsi sebagai awal sedangkan observasi awal adalah untuk mengetahui tindakan apa yang harus dilakukan dalam rangka meningkatkan hasil belajar siswa dalam menyelesaikan soal-soal.Teknik pengumpulan data yang digunakan dalam penelitian ini adalah teknik pengamatan/observasi dan tes (Leni Masnidar Nasution 2017).

Instrumen penelitian merupakan alat yang digunakan untuk mengukur suatu hal yang diamati. Instrumen yamg digunakan dalam penelitian ini adalah lembar observasi dan tes hasil belajar. Data yang telah dikumpul yang berupa pengamatan/observasi, tes tidak akan bermakna tanpa dianalisis yaitu diolah dan diinterpretasikan. Analisis data pada dasarnya bertujuan mengolah informasi kuantitatif maupun kualitatif sedemikian rupa sampai informasi itu menjadi bermakna (Rijali 2019).

Analisis data hasil observasi dalam penelitian ini dilakukan dengan cara analisis deskriptif. Adapun data siswa dianalisis dengan cara menghitung jumlah hasil observasi dan tes yakni ketuntasan hasil belajar siswa individual. kriteria ketuntasan belajar baik perseorangan maupun klasikal dapat disimpulkan bahwa hasil belajar dikatakan telah tuntas apabila presentase banyak siswa yang memperoleh nilai diatas KKM $(>60)$ mencapai 75\% sesuai dengan Yang dilakukan di Sekolah Dasar Negeri 110 Buton Kecamatan Wolowa Kabupaten Buton.

\section{HASIL DAN PEMBAHASAN PENELITIAN}

Hasil penelitian pada siklus satu menunjukkan data hasil belajar siswa siswa yang mendapat nilai dengan kategori rendah sebanyak 7 orang siswa (37\%) dengan kategori sangat rendah sebanyak 2 orang siswa $(10 \%)$. Sedangkan siswa termasuk dalam kategori tinggi sebanyak ada 8 orang siswa (43\%) dan yang termasuk dalam kategori sangat tinggi sebanyak 2 orang ( 10\%). Dapat dilihat paa tabel berikut:

Tabel 1. Keberhasilan Belajar Siswa Secara Klasikal Pada Siklus 1

\begin{tabular}{cccc}
\hline $\begin{array}{c}\text { Hasil Belajar } \\
\text { Siswa }\end{array}$ & $\begin{array}{c}\text { Tingkat Hasil } \\
\text { Belajar }\end{array}$ & Jumlah Siswa & $\begin{array}{c}\text { Persentase } \\
\text { Banyak Jumlah } \\
\text { Siswa }\end{array}$ \\
\hline $\mathbf{9 0 - 1 0 0}$ & Sangat Tinggi & $\mathbf{2}$ & $\mathbf{1 0 \%}$ \\
\hline $\mathbf{8 0 - 8 9}$ & Tingi & $\mathbf{8}$ & $\mathbf{4 3 \%}$ \\
\hline $\mathbf{7 0}-\mathbf{7 9}$ & Sedang & - & \\
\hline $\mathbf{5 5}-\mathbf{6 4}$ & Rendah & $\mathbf{7}$ & $\mathbf{3 7 \%}$ \\
\hline $\mathbf{0}-\mathbf{5 4}$ & Sangat Rendah & $\mathbf{2}$ & $\mathbf{1 0 \%}$ \\
\hline Jumlah & & $\mathbf{1 9}$ & $\mathbf{1 0 0 \%}$ \\
\hline Sumber : Hasil Olahan Data & &
\end{tabular}

Berdasarkan hasil pengolahan data pada siklus kedua menunjukkan bahwa Data hasil belajar siswa yang mendapat nilai dengan kategori rendah sebanyak 3 orang siswa $(15,79 \%)$, dengan kategori tinggi sebanyak 9 orang siswa (47,37\%). Dan siswa termasuk dalam kategori sangat tinggi ada 7 orang siswa $(36,84 \%)$. Data tersebut dapat dilihat melalui tabel berikut: 
3374 Meningkatkan Hasil Belajar Siswa pada Pelajaran PPKn dengan Menerapkan Model Paradigma Pedagogi Reflektif di Sekolah Dasar - Kamarudin

DOI: https://doi.org/10.31004/edukatif.v3i5.918

Tabel 2. Keberhasilan Belajar Siswa Secara Klasikal Pada Siklus 2

\begin{tabular}{cccc}
\hline $\begin{array}{c}\text { Hasil Belajar } \\
\text { Siswa }\end{array}$ & Tingkat Hasil Belajar & $\begin{array}{c}\text { Jumlah } \\
\text { Siswa }\end{array}$ & $\begin{array}{c}\text { Persentase Banyak } \\
\text { Jumlah Siswa }\end{array}$ \\
\hline $\mathbf{9 0}-\mathbf{1 0 0}$ & Sangat Tinggi & $\mathbf{7}$ & $\mathbf{3 6 , 8 4 \%}$ \\
\hline $\mathbf{8 0}-\mathbf{8 9}$ & Tingi & 9 & $\mathbf{4 7 , 3 7 \%}$ \\
\hline $\mathbf{7 0}-\mathbf{7 9}$ & Sedang & & \\
\hline $\mathbf{5 5}-\mathbf{6 4}$ & Rendah & $\mathbf{3}$ & $\mathbf{1 5 , 7 9 \%}$ \\
\hline $\mathbf{0}-\mathbf{5 4}$ & Sangat Rendah & - & \\
\hline Jumlah & & $\mathbf{1 9}$ & $\mathbf{1 0 0 \%}$ \\
\hline Sumber : Hasil Olahan Data & &
\end{tabular}

Berdasarkan penelitian, model Pembelajaran Paradigma Pedagogi Reflektif (PPR) ternyata dapat meningkatkan hasil belajar pada siswa kelas V Sekolah Dasar Negeri 110 Buton. Hal ini dikarenakan model penbelajaran Paradigma Pedagogi Reflktif (PPR) dalam proses pembelajaran dapat memodifikasi suasana belajar aktif, kreatif dan menyenangkan dalam berkolompok, sehingga membantu meningkatkan hasil belajar siswa terhadap materi yang disampaikan oleh guru.

Berdasarkan pengamatan yang dilakukan peneliti pada pre test yang telah dilaksanakan terdapat 4 orang siswa yang dikategorikan tuntas, sedangkan 15 orang siswa lainnya dikategorikan tidak tuntas. Hal ini menunjukkan bahwa siswa belum memahami dan mengerti tentang materi tersebut. Selama proses penelitian, peneliti melihat masih ada kesulitan dalam menyelesaikan soal yang telah diberikan, dan peneliti juga melihat kurangnya partisipasi siswa saat proses pembelajaran khususnya saat kerja kelompok berlangsung. Namun dari hasil tes siklus 1, dapat dilihat bahwa 10 siswa yang temasuk dalam kategori tuntas dan 9 orang termasuk dalam kategori tidak tuntas.

Setelah siklus 1 berlangsung maka peniliti melanjutkan pada siklus berikutnya yaitu siklus II. Dari hasil test siklus II dapat dilihat 16 siswa yang termasuk kedalam kategori tuntas dan 3 orang siswa dikategorikan dalam kategori tidak tuntas. Berdasarkan penjelasan dan rincian yang telah dibahas secara luas pada bagian hasil penelitian sebelumnya bahwasanya hasil belajar siswa kelas V Sekolah Dasar Negeri 110 Buton mengalami peningkatan. Hal tersebut terlihat pada persentase yang telah dijelaskan sebelumnya. Dengan demikian, dapat diambil kesimpulan bahwasanya pembelajaran Pendidikan Pancasila dan Kewarganegaraan (PPKn) materi peristiwa lahirnya pasncasila dan peran pancasila dalam keragaman bangsa menerapkan model pembelajaran Paradigma Pedagogi Reflektif (PPR) di Sekolah Dasar Negeri 110 Buton mengalami peningkatan hasil belajar siswa.

Angka hasil belajar siswa yang rendah terlihat pada pre-test sebanyak $21 \%$ yang hanya mencapai nilai tuntas. Kemudian setelah pelaksanaan tindakan dilaksanakan pada siklus Pre-Test Siklus I Siklus IIPersentase Ketuntasan21,00\% 52,60\% 84,21\%Jumlah Siswa 41016 Nilai Rata-Rata 51,84, 70, 81,57 Peningkatan Hasil Belajar mengalami peningkatan dengan angka persentase sebanyak 52,60\%, begitu juga dengan nilai rata-rata kelas serta jumlah siswa yang mengalami ketuntasan belajar juga bertambah menjadi 10 siswa. Kemudian pada siklus II terjadi lagi peningkatan dengan angka persentase sebesar 84,21\% dan jumlah siswa yang tuntas menjadi 16 siswa.

Bardasarkan pembahasan diatas, dapat disimpulkan bahwa terjadi peningkatan nilai dari mulai siklus I sampai ke siklus II telah memperoleh hasil yang memuaskan.Jika dilihat dari nilai rata-rata kelas yang mencapai 75 sudah melewati nilai KKM yang terdapat di kelas V Sekolah Dasar Negeri 110 Buton. Hal ini menunjukkan bahwa model pembelajaran Paradigma Pedagogi Reflektif (PPR) dapat meningkatkan hasil belajar siswa. 
3375 Meningkatkan Hasil Belajar Siswa pada Pelajaran PPKn dengan Menerapkan Model Paradigma Pedagogi Reflektif di Sekolah Dasar - Kamarudin

DOI: https://doi.org/10.31004/edukatif.v3i5.918

\section{KESIMPULAN}

Berdasarkan hasil dan pembahasan penelitian dapat diperoleh simpulan bahwa dengan menerapkan model pembelajaran Paradigma Pedagogi Reflektif (PPR) dapat meningkatkan hasil belajar siswa pada mata pelajaran Pendidikan Pancasila dan Kewarganegaraan (PPKn) materi peristiwa lahirnya Pancasila dan peran pancasila dalam menjaga keberagaman bangsa di kelas V Sekolah Dasar Negeri 110 Buton. Dapat di lihat dari tes prasiklus memperoleh nilai ketuntasan $21 \%$, sedangkan nilai yang tidak tuntas memperoleh $79 \%$. Kemudian di lakukan tindakan siklus I siswa memperoleh nilai yang tuntas 52,6\% dan yang tidak tuntas 47,3\%, kemudian pada siklus II terjadi peningkatan dengan angka persentase sebesar $84,21 \%$.

\section{UCAPAN TERIMA KASIH}

Terimakasih kepada ibunda Rektor Universitas Muhammadiyah Buton yang sudah memberikan dukungan dalam penelitian ini. Kepada pihak penerbit yang sudah bersedia memeriksa artikel dan menerbitkan artikel ini. Terimakasih kepada banyak pihak yang sudah berkontribusi atas penyelesaian penelitian ini sampai menjadi artikel penelitian.

\section{DAFTAR PUSTAKA}

Ananda, Azwar. 2012. "Pendidikan Kewarganegaraan Dan Pendidikan Karakter Bangsa Oleh: Azwar Ananda." Pendidikan Kewarganegaraan Dan Pendidikan Karakter Bangsa.

Fathurrochman, Irwan. 2017. "Implementasi Manajemen Kurikulum Dalam Upaya Meningkatkan Mutu Santri Pondok Pesantren Hidayatullah/Panti Asuhan Anak Soleh Curup." Tadbir: Jurnal Studi Manajemen Pendidikan.

Leni Masnidar Nasution. 2017. "Subagyo, Pangestu, (2003). Statistik Deskriptif. Yogyakarta: BPFEYogyakarta." Journal of The American Chemical Society.

Omeri, Nopan. 2005. "Pentingnya Pendidikan Karakter Dalam Dunia Pendidikan." Nopan Omeri.

Pranyoto, Yohanes Hendro. 2020. "Pengaruh Penggunaan Media Sosial Sebagai Media Pembelajaran Terhadap Hasil Belajar Kognitif Mahasiswa Sekolah Tinggi Katolik Santo Yakobus Merauke.”Jumpa.

Rijali, Ahmad. 2019. “Analisis Data Kualitatif.” Alhadharah: Jurnal Ilmu Dakwah.

Sudiyono, Lue, And Ni Wayan Karmini. 2020. "Character Education Through Social Guidance For Students.” Talent Development \& Excellence.

Wahana, Paulus, And Elisabeth Desiana Mayasari. 2007. "Pengaruh Penerapan Model Pembelajaran Inovatif Pada Matapelajaran Ppkn Terhadap Sikap Siswa Sd Akan Nilai-Nilai Terkait.” Jurnal Penelitian.

Widodo, Susilo Tri, Renggani Renggani, And Sukarjo Sukarjo. 2018. "Pengembangan Model Pembelajaran Project Citizen Berorientasi Civic Knowledge, Civic Disposition, Dan Civic Skill Sebagai Inovasi Dalam Mata Kuliah Pendidikan Pkn SD.” Pkn Progresif: Jurnal Pemikiran Dan Penelitian Kewarganegaraan.

Zhafran, Abdul. 2020. “A Peningkatan Hasil Belajar Pendidikan Kewarganegaraan Menggunakan Model Ppr Pada Siswa Kelas Iii Sdn 127/Ii Sungai Arang Kecamatan Bungo Dani.” Jurnal Tunas Pendidikan.

Zulfiati, Heri Maria. 2014. "Peran Dan Fungsi Guru Sekolah Dasar Dalam Memajukan Dunia Pendidikan." Trihayu: Jurnal Pendidikan Ke-SD-An. 